\title{
František Novosád: Osud a vol'ba. Max Weber o modernej spoločnosti
}

Bratislava, IRIS 2016, 188 s.

V roku 2016 bola filozofická obec obdarovaná d'alšou monografiou, ktorá vyšla z pera profesora Františka Novosáda, známeho slovenského filozofa, prekladatel'a, a do roku 2006 hlavného redaktora slovenského filozofického časopisu Filozofia. František Novosád sa špecializuje na dejiny filozofie 19. a 20. stor. a na výskum v oblasti politickej a sociálnej filozofie. Možno konštatovat', že väčšinu svojich prác sústredil na nemecké myslenie druhej polovice 19. a začiatku 20. storočia. Je preto viac menej pochopitel'né, že sa aj vo svojej vedeckej činnosti zameriava na problematiku fenoménu modernej spoločnosti a jej fungovania, že je motivovaný detegovat' hlavné princípy organizácie života spoločnosti a že východiskové stimuly hladá u nemeckých myslitel'ov. A preto ani nijako neprekvapí, že v rámci svojho súčasného vedeckého projektu Fenomén kultúry vo filozofickej reflexii (VEGA č. 2/0017/16) siahol po novej interpretácii klasického majstra myslenia, jedného z najvýznamnejších tvorcov sociológie Maxa Webera (1864 1920).

Vo svojej novej knihe Osud a vol'ba. Max Weber o modernej spoločnosti sa pokúsil nanovo prejst' kl'účové weberovské témy. A ako výstižne píše Miloslav Petrusek vo svojej recenzii, Novosád „ukázal všetky centrálne weberovské témy s tým, že ich väčšinou celkom prirodzene nechal vyzniet' vo filozofickej tónine“ (zadná strana obálky).

Kniha je rozdelená do deviatich kapitol. Prvá kapitola (s. 11 - 18) čitatel’a oboznamuje s dobou, v ktorej Weber žil a s jeho dielom, ktoré je zamerané na históriu, ekonómiu, politiku, vedu, právo, štátovedu atd'., pričom reflektovanie kauzálnych súvislostí a interdisciplinárny prístup sú základnými charakteristikami jeho myslenia. Novosád delí jeho tvorbu do troch skupín. Do prvej zarad'uje metodologické a teoretické reflexie Webera, do druhej jeho úvahy o genéze modernej spoločnosti a o genéze novovekého kapitalizmu a napokon do tretej skupiny patria štúdie o sociológii svetových náboženstiev. Autor vyslovuje presvedčenie, s ktorým treba súhlasit', a to, že „ked' chceme pochopit’ vývoj modernej spoločnosti a vnútornú „logiku“ súčasného myslenia o spoločnosti a dejinách, tak sa nezaobídeme bez poznania weberovského diela, jeho rozličných aspektov: metodologických, teoretických i svetonázorových“ (s. 17).

Druhá kapitola (s. 19 - 46) nesie názov Rámce možností. Otázka zameraná na to, čo je sociálna skúsenost', ktorá je reflektovaná vo vzt’ahoch spolupráce, konfliktu a l'ahostajnosti, privádza čitatel'a k úvahám o statuse vied o spoločnosti a načrtáva zamyslenie sa nad povahou a predmetom humanitných vied. Náčrt filozofických sporov o predmet či sporov o paradigmu vedie k reflexii o sociálnom konaní, čo je terminus technicus Maxa Webera. „Konanie“, ktoré odkazuje na „in- 
dividualistickú metódu“ vedie autora k otázke statusu sociológie ako možnosti koordinujúcej disciplíny, pričom ju analyzuje z pohl’adu evolucionalizmu.

Tretia kapitola (s. 47 - 65) nesie prít’ažlivý názov Veda ako reglementácia myslenia. Autor pozýva k úvahe nad zmenou epistémy, zmenou základnej mriežky, prostredníctvom ktorej hl'adíme na skutočnost' a konštatuje, že sa ustanovil nový typ poznania, odlišný od filozofie ako aj od prírodných vied. Od neurčitosti humanitných vied, ktorá vyplýva z ich povahy, sa autor sústred'uje na rozpad vel'kých systémov, reflektuje pozitivizmus, hermeneutiku a transcendentalizmus ako tri metodologické typy zdôvodňovania osobitosti vedy o spoločnosti. Pozornost' venuje poznávaniu individuálnych konštelácií a ich príčinných väzieb, čo je podl'a Webera základným ciel'om sociálnych vied. V kapitole nechýba reflexia klasických Weberových tém o ideálnom type v konotácii s Marxom či témy chápania, vysvetl'ovania a nakoniec fenoménu vedy, ktorá je pre Webera „istou formou askézy, spôsobom udržiavania odstupu od spontaneity života" (s. 65).

Štvrtá kapitola (s. 67 - 81) je pozvaním k reflexii nad racionalizáciou a jej paradoxmi. Racionalizácia je centrálnym bodom Weberovej „vízie dejín“. Autor nastol'uje myšlienku straty a zbavovania čara, ktoré podl'a Webera majú neblahé následky na celkovú orientáciu človeka a menia celú štruktúru svetonázorového vedomia. V racionalizácii sa jemne nastol'uje konfrontácia s kapitalizmom a socializmom. Zaujímavým je polohovanie myšlienok Webera a Foucaulta a ich chápanie modernity, čo asi nevyhnutne autora viedlo $\mathrm{k}$ tomu, aby načrtol tému dejinnosti spojenú s odlišnost’ou civilizácií a kultúr.

Zatial' čo štvrtá kapitola načrtla základné myšlienky kapitalizmu, piata kapitola (s. 83 - 107) je priamo v centre tejto problematiky. Weber by bez diela Protestantská etika a duch kapitalizmu nebol Weberom, akým sa zapísal do dejín myslenia. Jeho dielo je prítažlivé dodnes a rovnako prít’ažlivý je aj text F. Novosáda. Genealógia kapitalizmu je vlastne objavovaním logiky reglementácie života. Kapitalizmus ako konfiguráciu konaní, ako formu konania či ako výsledok stretnutia sa rozličných foriem racionalizácie Weber interpretuje ako obraz modernej spoločnosti. Osobitost'ou textu je to, že Novosád opät' konfrontuje myšlienky Webera s myšlienkami Marxa a táto polarizácia či skôr polemika je náležitá.

Šiesta kapitola (s. 109 - 129) vychádza z názoru, že dielo Maxa Webera „je orientované jedným základným problémom, a to problémom povahy modernity" (s. 109). Predmetom tejto kapitoly sa teda pochopitel'ne stávajú témy ako charakteristika modernity, charakteristika jej základnej črty, t. j. racionalizácie a z toho plynúce úvahy zamerané na racionalizované právo a štát alebo na dilemy racionalizovaného života. Tu sa autor usiluje formulovat' Weberov kl'účový problém v dvoch základných podobách: „Ako je možný život zoči-voči rozdielnym a často nezlučitel'ným životným poriadkom a ako sa to vlastne stalo, že človek sa dostal do konfrontácie so vzájomne sa vylučujúcimi životnými poriadkami?“ (s. 119). Odvolávajúc sa na B. Pascala, D. Huma, G. Leibniza, H. Rickera, G. Simmela, E. 
Cassirera či F. Nietzscheho dáva Novosád textu pravý filozofický kolorit. Nebudeme sa mýlit', ak budeme s autorom súhlasit' v tom, že žijeme „V epoche hodnotového polyteizmu, a každý z nás sa sám musí rozhodnút', čo je pre neho ,diablom a čo ,bohom“" (s. 124). Tu sa však nerieši polyteizmus náboženstva, ale polyteizmus vedy. Otázka statusu vedy, otázka sebakritiky, a teda otázka sebakritickej vedy uvol'nuuje pohl'ad na priestor vol'by. Problematickost' moderny sa teda otvorila ako tajomná skrinka plná byrokratických aparátov, a preto sa ako potrebné javí „načrtnút' čo i len trochu podrobnejšiu typológiu ciest, ktorými si moderný človek ,vyjednáva' svoju identitu v sporoch medzi vzájomne si konkurujúcimi a vzájomne sa vylučujúcimi životnými poriadkami“ (s. 128).

Ak chceme reinterpretovat' Webera v súvislosti s modernou spoločnost'ou, rozhodne nemôžeme obíst' jeho úvahy o politike. Toto je predmetom siedmej kapitoly (s. 131 - 156). Autor súhrne predkladá dve dimenzie weberových úvah o politike. Týkajú sa tak teoretického skúmania modernej spoločnosti, teda ide o opis štruktúr politična, no zároveň ide o úvahy, ktoré sledujú výsostne praktický motív. Weberovi išlo o nemecký kontext a o reflexiu politickej modernizácie. Aj tu Novosád správne uchopil Webera ako skvelého sociológa náboženstva a politiky. Témy zamerané na okruhy legitimity, konkrétne jej zdrojov a sily prirodzene autora vedú $\mathrm{k}$ sociológii panstva, $\mathrm{k}$ úvahám o moci, $\mathrm{k}$ jeho slávnym charizmám moci či k úvahám o praktickej dobovej politike, teda to, čo sa robí „dole“. Legitímnost”, vodcovstvo, mocenský aparát, politická elita, demagógie a pod., to všetko je reflektované s náležitým odstupom a erudovanost'ou.

V predposlednej ôsmej kapitole (s. 157 - 174) autor zdarne pokračuje v interpretácii politických kategórií, najmä kategórie charizmy. Z nie celkom úplnej, ale zato pre danú súvislost’ dostačujúcej teologickej interpretácie charizmy (autor charizmu interpretuje z hl'adiska morálnej teológie, avšak nevenuje sa charizme z pohl'adu pastorálnej teológie, čo je pre Weberov kontext kl'účové) vstupuje do krátkeho náčrtu diskurzu teológie a sociológie a následne v úvahe vyústi priamo v politickej sociológii. Je namieste otázka statusu charizmy a samozrejme jej povahy. Takisto artikulácia moci a charizmy má v autorových úvahách svoje miesto. V slovenskej spisbe je potreba tak teoretickej ako aj praktickej reflexie tejto artikulácie, a preto treba tento autorov vklad len privítat'.

V poslednej, deviatej kapitole (s. 175 - 184) sa autor zameriava na recepciu diela Maxa Webera na Slovensku. Monitoruje a sumarizuje rôzne preklady a vydania a dáva ich do historického kontextu. Doba bývalého Československa a doba normalizácie určitým spôsobom poznačili recepciu Webera a autor je profesionálne v obraze. Správne si kladie aj otázku, prečo sú ohlasy pred rokom 1989 ako aj po ňom na Webera skromnejšie. Odpoved' je hodná myslitel'a, ktorý sa vyzná nielen vo filozofii a sociológii, ale aj vintelektuálnej mentalite súčasných slovenských akademikov, filozofov a sociológov. Aj z tohto dôvodu sa oplatí knihu si prečítat'.

V závere možno konštatovat', že kniha je vel'mi dobrou sondou a takisto súborom fragmentálnych úvah do klasických weberovských tém, ktoré tvoria jeden 
celok. Kniha je tematicky vel'mi dobre komponovaná, aj ked' tlačiarenský škriatok aj tu urobil svoje dielo. Najviac je tým postihnutá siedma kapitole, v ktorej sa obsah na s. 6 nie celkom zhoduje so samotným obsahom v knihe. Celkovo však ide o knihu, ktorá rozhodne obohatí každú intelektuálnu knižnicu.

Tomáš Pružinec

\section{Literatúra}

NOVOSÁD, F. (2016) Osud a vol'ba. Max Weber o modernej spoločnosti. Bratislava: IRIS.

Doc. PhDr. ThDr. Tomáš Pružinec, PhD.

Univerzita Konštantína Filozofa v Nitre

Filozofická fakulta

Katedra filozofie

Hodžova 1

94901 Nitra

Slovenská republika

tpruzinec@ukf.sk

\section{Zlatica Plašienková (ed.): Bioetické výzvy a súčasnost'}

Bratislava, Stimul 2015, 287 s.

Súčasná bioetická problematika spojená s rýchlym rozvojom biotechnológií, biomedicínskeho a enviromedicínskeho výskumu, genetického inžinierstva a nanotechnológií, je charakterizovaná nielen interdisciplinaritou, ale aj názorovou a metodologickou pluralitou. $V$ minulom roku vyšla $v$ univerzitnom vydavatel'stve Stimul publikácia s názvom Bioetické výzvy a súčasnost', ktorá je výstupom vedecko-výskumnej aktivity 2.7 Spoločenské výzvy pre 21. storočie - bioetické výzvy $v$ kultúrnom rámci ${ }^{1}$. Recenzovaná publikácia je zborníkom obsahujúcim 24 odborných štúdií od 27 autorov a autoriek. Príspevky v tejto publikácii sú rozdelené do štyroch tematických celkov, čím sa zvyšuje zrozumitel'nost' a prehl'adnost' celého diela. Bioetická problematika je nazeraná z rôznych uhlov pohl'adu, a to práve podl'a odborného zamerania autorov. Otázky ohl'adne moderných trendov, ktorými

\footnotetext{
1 Aktivita je súčast'ou OP Výskum a vývoj pre dopytovo-orientovaný projekt: Univerzitný vedecký park Univerzity Komenského v Bratislave, ITMS 26240220086, ktorý je spolufinancovaný zo zdrojov Európskeho fondu regionálneho rozvoja.
} 